\title{
EFEITO DE DOSES E FONTES DE CARBOIDRATOS NO CRESCIMENTO DE PLANTAS DE GINSENG BRASILEIRO [Pfaffia glomerata (Spreng.) Pedersen] CULTIVADAS IN VITRO
}

\author{
FERNANDO TEIXEIRA NICOLOSO ${ }^{1}$ \\ ALAN CRISTIANO ERIG ${ }^{2}$ \\ DENISE RUSSOWSKI ${ }^{3}$ \\ CRISTIANE FLORES MARTINS ${ }^{4}$
}

\begin{abstract}
RESUMO - Pfaffia glomerata (Spreng.) Pedersen é uma das espécies de ginseng brasileiro usada popularmente como planta medicinal. Com este trabalho objetivou-se avaliar o efeito de doses $\left(15,30,45\right.$ e 60 g.L $\left.\mathrm{L}^{-1}\right)$ e fontes de carboidratos (sacarose, frutose, glicose, maltose e lactose) no crescimento dessas plantas cultivadas in vitro. $\mathrm{O}$ delineamento experimental foi o inteiramente casualizado com 15 repetições por tratamento. A parcela experimental consistiu de um tubo de ensaio contendo $10 \mathrm{~mL}$ de meio MS e um segmento nodal de $1,0 \mathrm{~cm}$ de comprimento e sem folhas. Os parâmetros avaliados aos 41 dias após a inoculação foram o número de brota-
\end{abstract}

ções, o número total de segmentos nodais por plântula, a altura média das brotações, a altura da maior brotação, a massa fresca e seca da parte aérea e a massa seca das raízes. A melhor fonte de carbono para o crescimento in vitro da $P$. glomerata foi a sacarose, e a lactose é inapropriada. O número total de segmentos nodais, altura média das brotações, altura da maior brotação, massa fresca e seca da parte aérea e a massa seca de raízes aumentam pelo acréscimo das doses de sacarose, e em

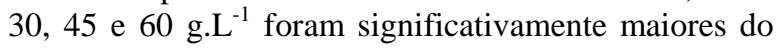
que aquelas proporcionadas pelas demais fontes de carbono.

TERMOS PARA INDEXAÇÃO: Cultura de tecidos, espécie medicinal, açúcares, Amaranthaceae.

\section{EFFECT OF CARBOHYDRATE CONCENTRATION AND SOURCE ON GROWTH OF BRAZILIAN GINSENG [Pfaffia glomerata (Spreng.) Pedersen] IN VITRO CULTURED PLANTS}

\begin{abstract}
Pfaffia glomerata (Spreng.) Pedersen is one of the brazilian ginseng species used as medicinal plant. The aim of this work was to evaluate the effect of carbohydrate concentration $\left(15,30,45\right.$, and 60 g.L $\left.\mathrm{L}^{-1}\right)$ and source (sucrose, fructose, glucose, maltose, and lactose) on the growth of plants grown in vitro. An entirely random statistical design with 15 replications per treatment was used. The experimental unity consisted of a test tube containing $10 \mathrm{~mL}$ of $\mathrm{MS}$ medium and 1-node segment of $1,0 \mathrm{~cm}$ length and without leaves. After 41 days of the inoculation the growth parameters analyzed were sprout number, total
\end{abstract}

number of nodal segment per seedling, average length of sprouts, length of the highest sprout, fresh and dry matter weight of aerial parts, and root dry matter weight. The best carbohydrate source for growth of $P$. glomerata in vitro cultured plants was sucrose, and lactose was found unsuitable. The total number of nodal segment per seedling, average length of sprouts, length of the highest sprout, fresh and dry matter weight of aerial parts, and root dry matter weight increase by sucrose concentrations, and at 30, 45 and 60 g.L $\mathrm{L}^{-1}$ all parameters were significantly higher than those obtained by other carbon sources.

INDEX TERMS: Tissue culture, medicinal specie, sugars, Amaranthaceae.

1. Engenheiro Agrônomo, Dr., Professor Adjunto, Departamento de Biologia, Centro de Ciências Naturais e Exatas, Universidade Federal de Santa Maria (UFSM), 97105-900, Santa Maria, RS. nicoloso@base.ufsm.br.

2. Engenheiro Agrônomo, Aluno do PPGA, Fruticultura de Clima Temperado, FAEM, Universidade Federal de Pelotas, bolsista CAPES.

3. Bióloga, Ms. Agronomia, Professora Substituta, Departamento de Biologia, UFSM.

4. Bióloga, Acadêmica do Curso de Pós-graduação em Biologia, UFSM. 


\section{INTRODUÇÃO}

A Pfaffia glomerata (Spreng.) Pedersen, pertencente à família Amaranthaceae, é uma espécie perene que cresce espontanemente principalmente entre a Região Centro-Oeste brasileira e o norte do Estado do Paraná, podendo atingir 2,0 $\mathrm{m}$ de altura (Smith \& Downs, 1972). Devido ao formato de suas raízes, muito semelhantes às do ginseng coreano (Panax ginseng C.A. Meyer) e às suas propriedades tônicas e estimulantes, a $P$. glomerata é também conhecida como ginseng brasileiro.

Em extratos de raízes de $P$. glomerata, vários metabólitos secundários foram identificados, tais como: ácido glomérico e ácido famérico, ecdisterona, rubrosterona, ácido oleanólico e oleanotato $\beta$-glicopiranosil (Shiobara et al., 1993). Recentemente, Michihiro et al. (1998) verificaram que o extrato de $P$. glomerata, de origem brasileira, administrado na dose de $1 \mathrm{~g} . \mathrm{kg}^{-1}$, induziu a maior taxa de natalidade, bem como espermatogênese vigorosa, histologicamente analisada, em hamsters machos. Além disso, a síntese de DNA em espermatogônia de ratos, tratados com o extrato a $1 \mathrm{~g} \cdot \mathrm{kg}^{-1}$, aumentou significativamente. Esses resultados indicam a presença de atividade estênica em $P$. glomerata.

As raízes de $P$. glomerata, bem como de $P$. paniculata Kuntze, são de grande interesse comercial, na forma de fitomedicamentos e suplementos alimentares, em razão de seu uso popular como antitumoral, antidiabetes e tônico afrodisíaco (Montanari et al., 1999). Por isso, tem ocorrido uma intensa exploração predatória das reservas naturais dessas espécies, justificando, portanto, que sejam elaborados planos de manejo ou projetos de cultivo.

Em condições de viveiro e em hidroponia sob ambiente controlado, foi verificado que a propagação vegetativa da $P$. glomerata via estaquia é viável. Contudo, o número de mudas obtidas é bastante reduzido em razão da pequena disponibilidade de estacas (média de 30) de ramos/planta de dois anos de idade (Nicoloso et al., 1999, 2001a). Considerando essa limitação potencial da estaquia como método de produção de plantas em larga escala, Nicoloso et al. (2001b) desenvolveram um protocolo altamente reproduzível para a micropropagação da $P$. glomerata, em que, a partir de um único segmento nodal, em meio de cultura MS (Murashige \& Skoog, 1962) suplementado com 30 g.L $\mathrm{L}^{-1}$ de sacarose, foi possível obter 15.000 plantas dentro de um período de seis meses.

No cultivo in vitro, as plantas perdem parcialmente o autotrofismo e, conseqüentemente, necessitam de uma fonte exógena de carboidratos. A melhor fonte e concentração de carboidrato (carbono reduzido) depende principalmente da espécie vegetal e da fase do processo de micropropagação. Borkowska \& Szczerba (1991) observaram que os açúcares sacarose, glicose, frutose e o álcool açúcar sorbitol favoreceram o crescimento de Prunus cerasus L. quando as suas concentrações estavam entre 20 e 30 g.L. ; $^{-1}$ porém, na presença de frutose, a proliferação foi a mais baixa; entretanto, esteve acoplada com a mais alta frequência de formação de brotações longas. Já para a micropropagação de Musa paradisiaca L., Folliot \& Marchal (1993) constataram que a substituição da frutose por sacarose, e o aumento da dose de 40 para 80 g. $\mathrm{L}^{-1}$ favoreceram o crescimento. Romano et al., (1995) verificaram que o requerimento de carboidratos durante o processo de micropropagação dependeu da fase do cultivo, em que a sacarose (30 g.L $\left.{ }^{1}\right)$ e a glicose $\left(40\right.$ g. $\left.\mathrm{L}^{-1}\right)$ foram as melhores fontes de carbono, respectivamente, durante a fase de proliferação e de enraizamento de Quercus suber L.

Com o presente trabalho objetivou-se avaliar o efeito de doses e fontes de carboidratos no crescimento de plantas de Pfaffia glomerata cultivadas in vitro.

\section{MATERIAL E MÉTODOS}

O experimento foi desenvolvido no Laboratório de Biotecnologia Vegetal pertencente ao Departamento de Biologia da Universidade Federal de Santa Maria (UFSM), RS.

O protocolo utilizado para a micropropagação da P. glomerata foi aquele descrito por Nicoloso et al. (2001b). Plantas com 40 dias de cultivo in vitro, com pelo menos uma brotação (comprimento médio de 7,5 $\mathrm{cm}$ ) contendo cinco segmentos nodais, foram utilizadas como fonte de explantes.

Os tratamentos consistiram da combinação de cinco fontes de carboidratos (sacarose, frutose, glicose, lactose e maltose; todas P.A.) e quatro concentrações dessas fontes $\left(15,30,45\right.$ e 60 g. $\left.\mathrm{L}^{-1}\right)$ adicionadas ao meio MS (Murashige \& Skoog, 1962), modificado apenas na concentração e fonte de carbono, como especificado pelo tratamento. Aos 41 dias após a inoculação, foram avaliados o número de brotações, o número total de segmentos nodais por plântula, a altura da maior brotação, a altura média das brotações, a massa fresca e seca da parte aérea e a massa seca das raízes.

$\mathrm{O}$ delineamento experimental foi o inteiramente casualizado com 15 repetições por tratamento. A parcela experimental consistiu de um tubo de ensaio $(25 \mathrm{~mm}$ de diâmetro, $150 \mathrm{~mm}$ de altura e $147,26 \mathrm{~cm}^{3}$ de volume interno) contendo $10 \mathrm{~mL}$ de meio MS, solidificado com 0,6\% de ágar, e um segmento nodal de 1,0 cm de com- 
primento e sem folhas. $\mathrm{O} \mathrm{pH}$ do meio de cultivo foi ajustado para 5,8 antes da inclusão do ágar e da autoclavagem $\left(1 \mathrm{~atm}, 120^{\circ} \mathrm{C}, 15 \mathrm{~min}\right)$. $\mathrm{O}$ cultivo dos explantes foi realizado em câmara climatizada com temperatura de $25 \pm 2{ }^{\circ} \mathrm{C}$ e fotoperíodo de $16 \mathrm{~h}$, sob intensidade luminosa de 1.500 lux fornecida por lâmpadas fluorescentes brancas-frias.

A análise dos dados foi realizada por regressão (fator doses de carboidratos) e por comparação de médias (fator fonte de carboidratos, dentro de cada dose) utilizando-se o software SOC/EMBRAPA - Campinas, SP.

\section{RESULTADOS E DISCUSSÃO}

O número de brotações por explante foi influenciado pela fonte e dose de carboidratos (Figura 1a). Tanto na metade da dose (15 g.. $\left.\mathrm{L}^{-1}\right)$ como naquela usualmente recomendada (30 g. $\left.\mathrm{L}^{-1}\right)$, o efeito da sacarose igualou-se ao da lactose, onde houve o menor número de brotações, apesar de ter ocorrido aumento desse parâmetro pelo acréscimo dessas duas fontes de carboidratos. Ao contrário do observado para sacarose, que influenciou de modo positivo e linear, a lactose em dose superior a $30 \mathrm{~g} . \mathrm{L}^{-1}$ reduziu o número de brotações, tornando-se a pior fonte de carbono. A frutose, glicose e maltose, na dose de 15 e 30 g. $\mathrm{L}^{-1}$, proporcionaram respostas semelhantes, sendo superiores àquelas da sacarose e lactose. A partir de 45 g. $\mathrm{L}^{-1}$, o efeito da sacarose igualou-se ao da frutose e maltose, e essas fontes foram superiores à glicose, que reduziu linearmente o número de brotações. Em qualquer dose das fontes de carbono testadas, o mais alto número de brotações obtido (média $=1,80$ ) foi semelhante àquele observado para mesma espécie por Nicoloso et al. (2001b), demonstrando que a $P$. glomerata não apresenta grande plasticidade quanto ao número de brotações.

O número total de segmentos nodais produzidos por plântula foi maior com uso da sacarose nas doses de 30, 45 e 60 g.L - $^{-1}$ (Figura 1b). Entretanto, o maior valor obtido (ponto de máxima eficiência técnica estimada $=$ $7,40)$ foi semelhante àquele observado por Nicoloso et al. (2001b) em P. glomerata. Isso demonstra que apesar de a sacarose sobressair-se sobre as demais fontes de carbono testadas, nesse importante parâmetro de crescimento, visando a uma alta taxa de multiplicação para produção de mudas em larga escala, o acréscimo na dose de sacarose, sob o ponto de vista custo/benefício, não traria aumento significativo.

A altura média das brotações (Figura 1c) e altura da maior brotação (Figura 1d) também foram maiores quando a sacarose foi a fonte de carbono utilizada, nas doses de 30, 45 e 60 g.L. $\mathrm{L}^{-1}$. Diferentemente do que aconteceu para o número de brotações (Figura 1a) e número total de segmentos nodais (Figura 1b), os valores da altura média das brotações e da altura da maior brotação são maiores do que aqueles observados em $P$. glomerata por Nicoloso et al. (2001b), que registraram valores de, respectivamente, 6,3 e $8,0 \mathrm{~cm}$ nesses parâmetros; demonstrando que o aumento da dose de sacarose, como já constatado por Romano et al. (1995) em Quercus suber L., favorece a elongação das brotações, permitindo um maior aproveitamento dos segmentos nodais durante a repicagem.

Nas doses de 30, 45 e 60 g.L $\mathrm{L}^{-1}$, as massas fresca (Figura 2a) e seca (Figura 2b) da parte aérea, bem como a massa seca de raízes (Figura 2c) também foram maiores na presença de sacarose do que com qualquer outra fonte de carbono. Interessantemente, a massa seca das raízes (Figura 2c) foi influenciada mais drasticamente, apresentando resposta linear ao aumento da dose de sacarose, do que a parte aérea, que teve resposta cúbica. Desse modo, os quocientes entre a massa seca de raízes e da parte aérea, que foram em média de $0,37,0,36$, 0,69 e 0,81 , respectivamente nas doses de $15,30,45$ e 60 g.L. ${ }^{-1}$ de sacarose, alteraram-se consideravelmente. Sabe-se que o sucesso no pegamento de mudas de espécies florestais (Daniel et al., 1997) é dependente desse quociente, e valores próximos a 0,5 são ideais. Portanto, apesar do aumento geral na produção de massa seca dos órgãos da $P$. glomerata pela elevação da concentração da sacarose, sugere-se pesquisas futuras no sentido de estabelecer qual seria a melhor dose dessa fonte de carbono para a fase de aclimatização e pegamento das mudas. Na formação de raízes adventícias de Quercus suber L., Romano et al. (1995) observaram que essa foi fortemente dependente do suprimento de carboidratos, sendo a glicose a fonte de carbono mais efetiva na promoção do enraizamento, seguida da sacarose e da frutose filtrada e esterelizada. Entretanto, a resposta do enraizamento, induzida pela frutose, dependeu do procedimento de esterilização, em que a frutose autoclavada não apresentou resultados positivos. Diferentemente de outras espécies, principalmente das lenhosas, a $P$. glomerata cultivada in vitro dentro de um período de $35 \pm 5$ dias, após a inoculação, apresenta excelente desenvolvimento do sistema radicular junto aquele da parte aérea (dados deste trabalho e de Nicoloso et al., 2001b), evidenciando que para a micropropagação dessa espécie não é necessário usar diferentes fontes de carbono para melhorar o crescimento da plântula como um todo. 
O uso da sacarose como a mais usual fonte de carbono para o cultivo in vitro, visando aos mais variados propósitos, tem sido observado para muitas espécies vegetais. Sul \& Korban (1998), testando três fontes de carbono (sacarose, glicose e frutose) na indução de gemas adventícias de embriões de Pinus sylvestris L., observaram que os explantes cultivados no meio Gresshoff e Doy contendo sacarose produziram a mais alta freqüência de regeneração ( $81 \%$ ), bem como ausência de hiperhidricidade das brotações adventícias. Em cultura de raízes de Panax ginseng C.A. Meyer, foi constatada ótima produção de biomassa, bem como o mais alto conteúdo de ginsenosídeo, na presença de $30 \mathrm{~g} . \mathrm{L}^{-1}$ de sacarose (Odnevall \& Bjork, 1989). Esses mesmos autores verificaram que as enzimas para a degradação da sacarose e da maltose estavam presentes nas frações da parede celular e que a glicose e frutose foram simultaneamente usadas pelas culturas de raízes; porém, as culturas menos diferenciadas usaram toda glicose disponível antes da utilização da frutose.
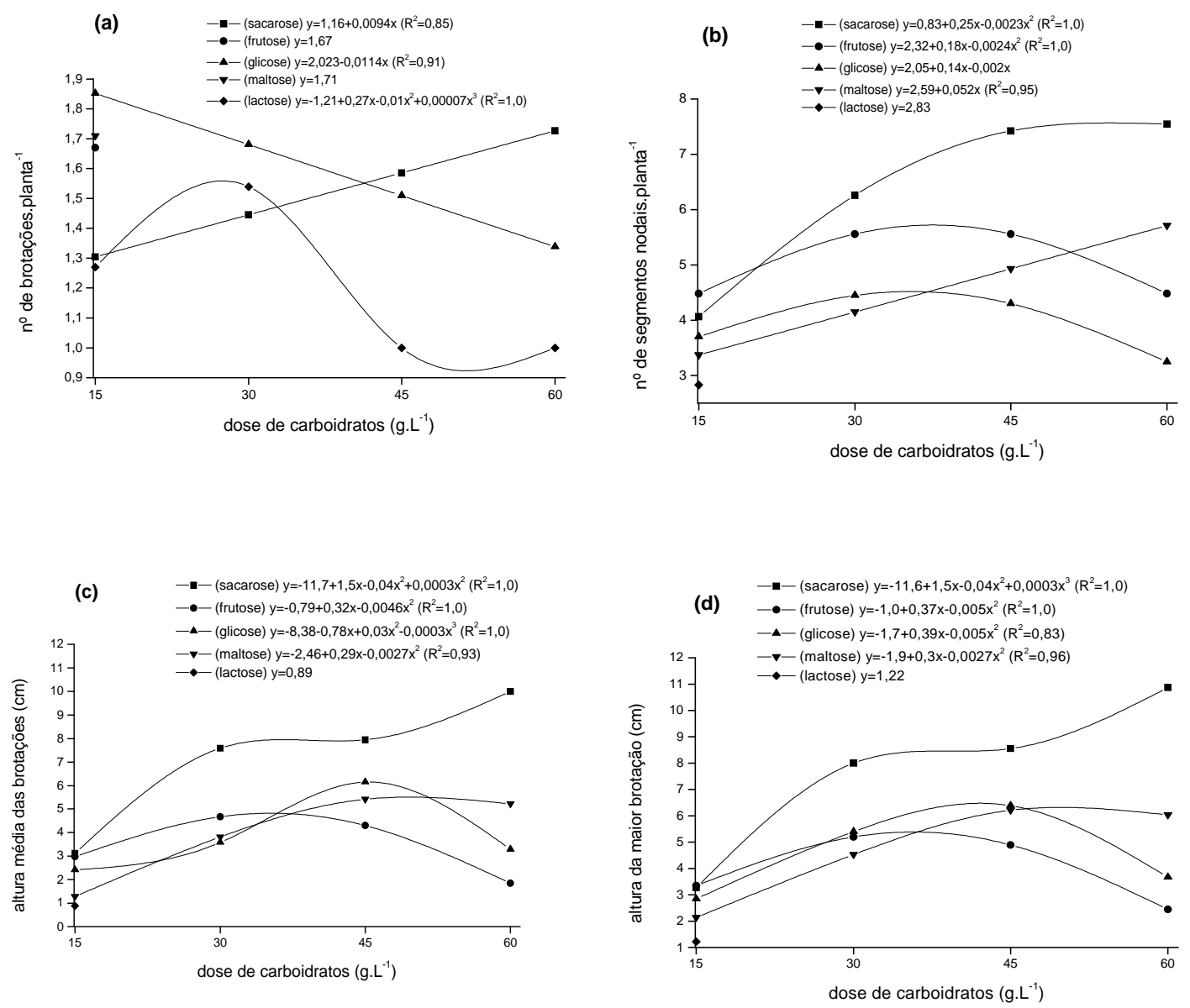

FIGURA 1 - Efeito de doses de sacarose, frutose, glicose, maltose e lactose no número de brotações (a), número total de segmentos nodais (b), altura média das brotações (c) e altura da maior brotação (d) por plântula de Pfaffia glomerata, aos 41 dias após a inoculação. 

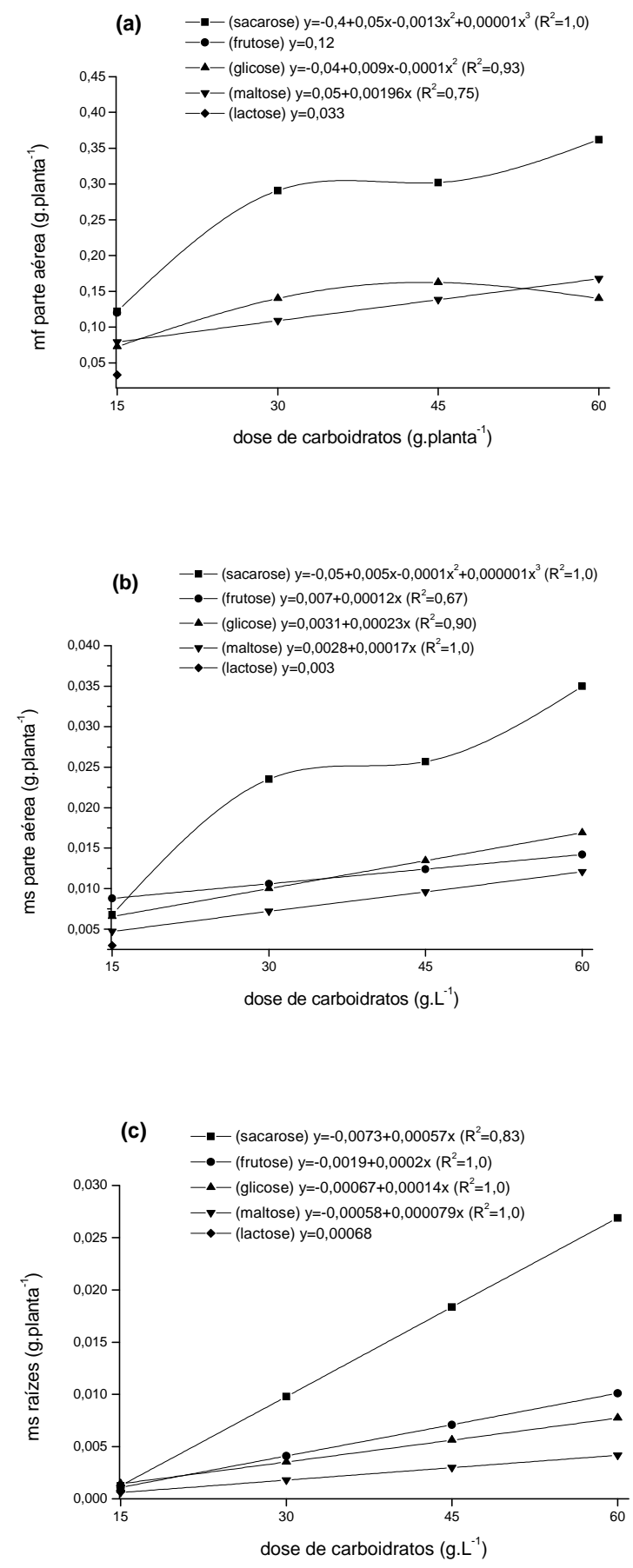

FIGURA 2 - Efeito ae aoses ae sacarose, Irutose, giıcose, maltose e lactose na massa fresca da parte aérea (a), massa seca da parte aérea (b) e massa seca das raízes (c) por plântula de Pfaffia glomerata, aos 41 dias após a inoculação.

Ciênc. agrotec., Lavras. V.27, n.1, p.84-90, jan./fev., 2003 
A preferência pela frutose em relação à sacarose, como fonte de carbono, por algumas espécies e tecidos, pode estar relacionada à necessidade de as células excretarem a enzima invertase ao meio de cultivo, visando à hidrólise da sacarose antes da absorção da fonte de carbono (Hew \& Mah, 1989). No presente experimento com $P$. glomerata, verificou-se que a sacarose foi a melhor fonte de carbono para o crescimento; portanto, essa espécie não apresenta dificuldades em absorver a sacarose diretamente do meio e/ou também seus produtos de hidrólise.

A lactose como fonte alternativa de carbono, sendo um subproduto residual da indústria do leite, não foi adequada ao crescimento da $P$. glomerata em quase todos parâmetros de crescimento analisados (Figuras 1b, 1c, 1d, 2a, 2b e 2c), sendo exceção o número de brotações na dose de 30 g.L $\mathrm{L}^{-1}$, que se igualou à sacarose (Figura 1a). Efeitos negativos desse carboidrato também foram observados em outras espécies. Callebaut \& Motte (1988) constataram que a utilização da lactose junto ao meio MS em cultura de células em suspensão de $\mathrm{Cu}$ cumis sativus L. começou somente após uma longa fase lag e foi acompanhada por um aumento na atividade extracelular de $\beta$-galactosidase específica de lactose. Além disso, a adição de sacarose, como fonte suplementar de carbono, teve efeito de reduzir a duração da fase lag. Desse modo, os resultados obtidos em $P$. glomerata, semelhantes aos verificados para outras plantas, demonstram que essa espécie talvez não possua um sistema eficiente para a absorção e utilização da lactose (Figura 1a).

A fonte de carbono para o cultivo de vegetais in vitro pode alterar a estrutura do aparato fotossintético e, também, seu funcionamento. Dalton \& Street (1977) e Gro et al. (1993) observaram, respectivamente, em cutura de Spinacea oleracea L. e Arachis hypogea L., que o conteúdo de clorofila e Rubisco, bem como a sua atividade, decresceram quando açúcares prontamente assimiláveis (sacarose, glicose, frutose e maltose) foram adicionadas ao meio de cultura, enquanto outras fontes de carbono, tais como inulina e rafinose, estimularam o acúmulo de clorofila em culturas de Spinacea oleracea. Em calos de Zea mays L., a sacarose foi incapaz de promover a obtenção de culturas fotomixotróficas estáveis (Solís et al., 1989).

Desse modo, o benefício advindo do aumento da concentração de sacarose, de 30 até 60 g.L. $\mathrm{L}^{-1}$ no meio de cultivo, apesar de indicar um ganho sob o ponto de vista da obtenção de um maior número de explantes (Figura 1b), visando à propagação em larga escala, bem como maior tamanho das brotações (Figuras 1c, 1d) e maior produção de massa fresca e seca (Figuras 2a, 2b, 2c), pode não representar uma situação de melhor condição fisiológica das plântulas durante o processo de aclimatização, em que consideráveis modificações morfofisiológicas devem ocorrer, como já constatado na transferência das plantas de $P$. glomerata cultivadas in vitro, na presença ou ausência de benzilaminopurina, para o ambiente ex vitro (Sartori, 2000). Essa observação vem ao encontro dos resultados de Serret et al. (1997), em que o decréscimo na concentração de sacarose (de 30 para 15 g. $\mathrm{L}^{-1}$ ) no meio de cultivo induziu a um maior grau de desenvolvimento foto-autotrófico de plântulas de Gardenia jasminoides Ellis durante dois estágios sucessivos de cultivo (multiplicação de brotações e indução radicular).

\section{CONCLUSÕES}

A melhor fonte de carbono para o crescimento in vitro da $P$. glomerata é a sacarose, sendo a lactose inapropriada.

O número total de segmentos nodais, altura média das brotações, altura da maior brotação, massa fresca e seca da parte aérea e a massa seca de raízes aumentaram pelo acréscimo das doses de sacarose, e em 30, 45 e $60 \mathrm{~g} . \mathrm{L}^{-1}$ foram superiores àquelas proporcionadas pelas demais fontes de carbono.

\section{AGRADECIMENTOS}

À FAPERGS, CNPq e FIPE/UFSM, pelo financiamento deste trabalho.

\section{REFERÊNCIAS BIBLIOGRÁFICAS}

BORKOWSKA, B.; SZCZERBA, J. Influence of different carbon sources on invertase activity and growth of sour cherry (Prunus cerasus L.) shoot cultures. Journal of Experimental Botany, Oxford, v. 42, n. 240, p. 911-915, 1991.

CALLEBAUT, A.; MOTTE, J. C. Growth of cucumber cells in media with lactose or milk whey as carbon source. Plant Cell Reports, New York, v. 7, n. 3, p. 162-165, 1988

DALTON, C. C.; STREET, H. E. The influence of applied carbohydrates on the growth and greening of cultured spinach (Spinacea oleracea L.) cells. Plant Science Letters, Amsterdam, v. 10, p. 157-164, 1977.

DANIEL, O.; VITORINO, A. C. T.; ALOVISI, A. A.; MAZZOCHIN, L.; TOJURA, A. M.; PINHEIRO, E. R.; 
SOUZA, E. F. de. Aplicação de fósforo em mudas de Acacia magnum Willd. Revista Árvore, Viçosa, v. 21, n. 2, p. 163-168, 1997.

FOLLIOT, M.; MARCHAL, J. In vitro growth of bananas (cv. Grande Naine): study of utilization of the carbon source and the main mineral elements of the culture medium. Fruit Paris, Paris, v. 47, n. 5, p. 565$571,1993$.

GRO, B.; GILLES, F.; BENDER, L.; BERGHOFER, P.; NEUMANN, K. The influence of sucrose and an elevated $\mathrm{CO}_{2}$ concentration of photosynthesis of photoautotrophic peanut (Arachis hypogea L.) cell cultures. Plant Cell, Tissue and Organ Culture, Hague, v. 33, p. 143-150, 1993.

HEW, C. X.; MAH, T. C. Sugar uptake and invertase activity in Dendrobium tissues. New Phytologist, Cambridge, v. 111, n. 2, p. 167-171, 1989.

MICHIHIRO, K.; YASUHIRO, T.; TOSHIHARU, H., SHIGEYUKI, A; MASAO, I.; MASASHI, K. Enhancing effect of brazilian Pfaffia glomerata on reproductive ability of male golden hamsters and of male mice. Natural Medicines, London, v. 52, n. 1, p. 68-73, 1998.

MONTANARI, I. J.; MAGALHÃES, P. M.; QUEIROGA, C. L. Influence of plantation density and cultivation cycle on root productivity and tenors of $\beta$ ecdysone in Pfaffia glomerata (Spreng) Pedersen. Acta Horticulturae, Wageningen, v. 3, n. 502, p. 125-129, 1999.

MURASHIGE, T.; SKOOG, F. A revised medium for rapid growth and bioassays with tobacco tissue cultures. Physiologia Plantarum, Copenhagen, v. 15, p. 473497, 1962.

NICOLOSO, F. T.; FORTUNATO, R. P.; FOGAÇA, M. A. F. Influência da posição da estaca no ramo sobre o enraizamento de Pfaffia glomerata (Spreng.) Pedersen em dois substratos. Ciência Rural, Santa Maria, v. 29, n. 2, p. 277-283, 1999.

NICOLOSO, F. T.; CASSOL, L. F.; FORTUNATO, R. P. Comprimento da estaca de ramo no enraizamento de ginseng brasileiro (Pfaffia glomerata). Ciência Rural, Santa Maria, v. 31, n. 1, p. 57-60, 2001a.

NICOLOSO, F. T.; ERIG, A. C.; MARTINS, C. F.; RUSSOWSKI, D. Micropropagação do ginseng brasileiro [Pfaffia glomertata (Spreng.) Pedersen]. Revista
Brasileira de Plantas Medicinais, Botucatu, v. 3, n. 2, p. 11-18, 2001b.

ODNEVALL, A.; BJORK, L. Differentiated tissue cultures of Panax ginseng and their response to various carbon sources. Biochemie und Physiologie der Pflanzen, [S.1.], v. 185, n. 5-6, p. 403-413, 1989.

ROMANO, A.; NORONHA, C.; MARTINSLOUCAO, M. A. Role of carbohydrates in micropropagation of cork oak. Plant Cell, Tissue and Organ Culture, Hague, v. 40, n. 2, p. 159-167, 1995.

SARTORI, J. S. Aspectos anatômicos da lâmina foliar de Pfaffia glomerata (Spreng.) Pedersen (Amaranthaceae) cultivada em diferentes condições ambientais. 2000. 52 p. Monografia (Especialização em Biologia) - Universidade Federal de Santa Maria, Santa Maria.

SERRET, M. D.; TRILlAS, M. I.; MATAS, J.; ARAUS, J. L. The effect of different closure types, light, and sucrose concentrations on carbon isotope composition and growth of Gardenia jasminoides plantlets during micropropagation and subsequent acclimation ex vitro. Plant Cell, Tissue and Organ Culture, Hague, v. 47, n. 3, p. 217-230, 1997.

SHIOBARA, Y.; INOUE, S.; KATO, K.; NISHIGUCHI,Y.; OISHI, Y.; NISHIMOTO, N.; OLIVEIRA, F. de; AKISUE, G.; AKISUE, M. K,; HASHIMOTO, G. A nortriterpenoid, triterpenoid and ecdysteroids from Pfaffia glomerata. Phytochemistry, Oxford, v. 32, n. 6, p. 1527-1530, 1993.

SMITH, L. B.; DOWNS, R. J. Flora Ilustrada Catarinense: amarantáceas. Itajaí: [s.n.], 1972. 110 p.

SOLÍS, C.; SÁNCHEZ DE JIMÉNEZ, E.; LOYOLAVARGAS, V. M.; CÁRABEZ, A.; LOTINAHENNSEN, B. The biogenesis of chloroplasts in tissue cultures of a C3 and C4 plant. Plant and Cell Physiology, Kyoto, v. 30, p. 609-616, 1989.

SUL, I.; KORBAN, S. S. Effects of media, carbon sources and cytokinins on shoot organogenesis in the Christmas tree Scots pine (Pinus sylvestris L.). Journal of Horticultural Science and Biotechnology, Ashford, v. 73, n. 6, p. 822-827, 1998. 